Lurnas $¥$ fukum

\title{
SEJARAH PEMIKIRAN HUKUM ISLAM DI INDONESIA
}

\author{
MUZAKKIR \\ Dosen Fakultas Syariah Institute Agama Islam Negeri Langsa \\ Jl. Meurandeh, Langsa Lama, Kota Langsa - Aceh \\ muzakkirsamidanprang@gmail.com
}

\begin{abstract}
The thinking of Islamic law that has been institutionalized and obeyed by Indonesian society is figh, the fatwa of ulama-judge, court decisions (jurisprudence) and legislation. The process of the birth of the four things is inseparable from the development of the dynamics of the life of the Indonesian people. The Islamic legal thinking adopted in the development of Islamic law in Indonesia has long been proclaimed by the Islamic scholars of Islam in the Islamic world with various kinds of works that they have born. The scholars of Islamic law such as Imam Shafi', Imam Ahmad bin Hanbal and scholars afterwards. The existence of local wisdom makes it a part of consideration in every thought of Islamic law in Indonesia, such as marriage and inheritance law that highly respects the social life of the community, both existing and developing since the beginning and the development of social life of the community. Keywords:
\end{abstract}

\begin{abstract}
Abstrak, Pemikiran hukum Islam yang telah dilembagakan dan dipatuhi oleh masyarakat Indonesia adalah figh, fatwa ulama, keputusan pengadilan (yurisprudensi) dan perundangundangan. Proses lahirnya keempat hal tersebut tidak terlepas dari perkembangan dinamika kehidupan masyarakat Indonesia. Pemikiran hukum Islam yang diadopsi dalam pengembangan hukum Islam di Indonesia telah lama diproklamirkan oleh para cendekiawan Islam Islam di dunia Islam dengan berbagai macam karya yang telah mereka lahirkan. Para ulama hukum Islam seperti Imam Syafi'i, Imam Ahmad bin Hanbal dan ulama sesudahnya. Keberadaan kearifan lokal menjadikannya bagian dari pertimbangan dalam setiap pemikiran hukum Islam di Indonesia, seperti hukum perkawinan dan pewarisan yang sangat menghormati kehidupan sosial masyarakat, baik yang sudah ada maupun yang berkembang sejak awal dan perkembangan kehidupan sosial masyarakat.
\end{abstract}

Kata kunci:

\section{Pendahuluan}

Bangsa Indonesia merupakan bangsa yang mutlikultural dan majemuk dari segi suku bangsa, ras, budaya dan agama. Oleh karena itu pembentukan hukum nasional tidak boleh mengabaikannya, berlandaskan pada epistemologi yang berintikan rasa keadilan,kebenaran, nilai sosial dan kultural, serta norma agama yang hidup di tengahmasyarakat itulah, hukum nasional dibangun dan dikembangkan.

Hukum Islam yang menjadi bagian tak terpisahkan dari ajaran agama Islam,merupakan sumber hukum yang penting untuk dilembagakan di Indonesia. Karenasecara empirik hukum Islam merupakan hukum yang hidup (the living law) ${ }^{1}$ dalam

\footnotetext{
${ }^{1}$ Abdul Manan, Reformasi Hukum Islam di Indonesia,(Jakarta:Rajawali Press, 2006), hlm. 22.
} 
masyarakat Indonesia mulai sejak masuknya Islam ke Nusantara yang menurut JC. Van Leur sejak abad ke tujuh. ${ }^{2}$ Namun kemudian beberapa aspek atau bidang tertentu dari hukum Islam belum dijadikan hukum positif oleh kekuasaan negara, atau paling tidak keberlakuannya tetap dalam bayang-bayang hukum adat.

Hal ini merupakan akibat panjang dari rekayasa politik hukum kolonial Belanda dan jugarekayasa ilmiah kaum intelektual Belanda yang secara sistematik memarginalkan hukum Islam. ${ }^{3}$

Pada masa kejayaan kerajaan di Nusantara, hampir semua bidang hukum Islam baik pidana maupun perdata sudah pernah berlaku sebagai hukum dalam kerajaan di Nusantara, meskipun kemudian dalam perkembangan selanjutnya dianulir oleh Belanda.Bahkan termasuk aspek pidananya yang telah berlaku di kerajaan Nusantara pernah dihimpun oleh pemerintah kolonial Belanda sendiri sebagai panduan pejabat pemerintahan dan hakim dalam penyelesaian perkara antara orangIslam di landraad yang dikenal dengan compendium. Misalnya pada tahun 1747 Compendium Mogharaer Code diterbitkan di Semarang, lalu pada tahun 1759 Compedium Clootwijck di Sulawesi dan pada tahun 1761 diterbitkan Compendium Freijer. Demikian juga ilmuwan Belanda Winter, Solomon Keyzer dan terutama LWC van Der Berg menyimpulkan dalam teorinya yang terkenal, receptie incomplexu bahwa hukum yang sebenarnya berlaku bagi masyarakat pribumi di Nusantara adalah hukum Islam. ${ }^{4}$ Namun, setelah bangsa kolonial semakin kuat berkuasa, dengan kekuatan senjata melesakkan kehidupan hukum sekulernya ke relung jiwa masyarakat Nusantara, ummat Islam dipisahkan dari hukum agama yang dianutmereka.

Meskipun harus diakui, Belanda masih memberlakukan hukum keluargaIslam dalam kebijakan politik hukumnya. Pada tahun 1760 kebijakan politik hukum pemerintah Belanda mengeluarkan residentie der Islamicsh untukmenjamin pelaksanaan hukum keluarga Islam, yang antara lain menyebutkan hakim melandaskan hukumnya pada undang-undang agama (goedsdienstigewetten). ${ }^{5}$

Hanya saja pada akhirnya --lagi-lagi demi kepentingan kolonial - oleh Souck Hurgronye disusun teori baru yaitu receptie theorie yang kemudian dimantapkembangkan oleh Van Vollenhoven. Teori ini telah memutar-balikkan fakta, karena menganggap hukum Islam hanya berlaku ketika diterima (di-receptie).

\section{Pembahasan}

\footnotetext{
${ }^{2}$ Hassan Muarif Ambary, Menemukan Jejak Arkeologis dan Historis Islam, (Jakarta:Logos,1998), hlm. 56-58.

${ }^{3}$ Bustanul Arifin, Dimensi Hukum Islam dalam Hukum Nasional, (Gema Insani Press, 1999), hlm. 33.

${ }^{4}$ Said Aqil Husein Al Munawwar, Islam dalam Pluralitas Masyarakat Indonesia, (Jakarta: Kaifa,2004),hlm. 271.

${ }^{5}$ Ismail Sunny, Kompilasi Hukum Islam Ditinjau dari Teori Hukum, dalam TimDitbinbapera, Berbagai Pandangan Mengenai Kompilasi Hukum Islam, (Jakarta:Yayasan Al Hikmah,1996), hlm. 56.
} 


\section{A. Kondisi Sosial Dan Politik}

Kondisi politik yang memberi pengaruh besar pada pemikiran hukum Islam di Nusantara ialah berdirinya kerajaan-kerajaan Islam pada saat itu. Kerajaan-kerajaanIslam inilah yang memiliki peran besar dalam pengembangan agama Islam padaumumnya dan pemikiran hukum Islam pada khususnya.

Pada abad ke17, kerajaan Islam yang berdiri pada waktu itu adalah kerajaan Aceh Darussalam. Kerajaan Aceh Darussalam yang diproklamasikan pada tanggal 12 Zulkaedah 916 H $(1511 \mathrm{M})$ adalah hasil peleburan kerajaan Islam Aceh dibelahan barat dan kerajaan Islam Samudra Pasai di belahan timur. Dimana kerajaan Islam Pasai mengalami kemunduran, dan kerajan Malaka mengalami kemunduran,maka di saat itulah kerajaan Aceh Darussalam mulai berkembang. ${ }^{6}$

Aceh pada saat itu merupakan sumber ilmu pengetahuan dengan sarjana-sarjananya yang terkenal di dalam dan di luar negeri, sehingga banyaklah orang luaryang datang ke Aceh untuk menuntut ilmu. Bahkan ibu kota kerajaan AcehDarussalamterus berkembang menjadi kota internasional dan menjadi pusat perkembangan ilmupengetahuan dan kebudayaan.

Kerajaan Aceh Darussalam mendapatkan perhatian yang sangat besar. Pada saat itu terdapat lembaga-lembaga negara yang bertugas dalam bidang pendidikan dan ilmu pengetahuan. Diantara lembaga tersebut adalah; pertama:balai seutia hukama; merupakan lembaga ilmu pengetahuan, tempat berkumpulnya para ulama, ahli pikir dan cendikiawan untuk membahas dan mengembangkan ilmu pengetahuan. Kedua: balai seutia ulama. Merupakan jawatan pendidikan yang bertugas mengurus masalah-masalah pendidikan dan pengajaran.

Adapun jenjang yang ada adalah sebagai berikut:

1. Meunasah (Madrasah/Ibtida'iyah)

2. Rangkang (Madrasah Tsanawiyah)

3. Dayah (Madrasah Aliyah)

4. Dayah Teuka Cik (Perguruan Tinggi). ${ }^{8}$

Pada kerajaan Islam Aceh Darussalam, ilmu pengetahuan benar-benar berkembang dengan pesat dan mampu melahirkan ulama dan ahli ilmu pengetahuan seperti: Hamzah Fansuri, Syekh Samsudin Sumatrani, Syekh Nurudin al-Raniri dan Syekh Abdul Rauf alSinkili.

\section{B. Kondisi Intelektual dan Pemikiran Hukum Islam}

Secara umum kegiatan intelektual di Nusantara telah terjadi sebelum abad ke 17M. sebagaimana fenomena mengapa hukum Islam yang berkembang di Nusantara

\footnotetext{
${ }^{6}$ Muhammad Rifai, Sejarah Islam, (Semarang: Wicaksana, 1985), hlm. 86.

${ }^{7}$ Hasbullah, Sejarah Pendidikan Islam di Indonesia (Jakarta: Raja Grafindo Persada, 1999), hlm. 31.

${ }^{8}$ Ibid, hlm. 32.
} 
didominasi oleh madzhab Syafi'i, maka jawabannya terdapat ketika pembawa agama Islam pertama kali ke Nusantara merupakan penganut madzhab Shafi'i. Adapun agama Islam masuk ke Nusantara terjadi pada abad ke 7 atau $8 \mathrm{M}$, dengan madzhabnya AsySyafi'i berkembang dan bertahan hingga berdirinya kerajaan Islam pertama yang berada di Nusantara yaitu kerajaan Samudera Pasai pada abad ke 10 M,dengan raja pertamanya al-Malik Ibrahim bin Makhdum.

Ibnu Batutah menuturkan bahwa ia sangat mengagumi akan keadaan kerajaan Pasai, dimana rajanya sangat 'Alim dan begitu pula dalam ilmu agamanya, dengan menganut madzhab Syafi'i dan serta mempraktekkan pola hidup yang sederhana. ${ }^{9}$

Adapun pada abad ke 17, potret intelektual Nusantara terwakili oleh tiga ulama,mereka adalah Nurudin al-Raniri dan Abd Rauf al-Sinkili di Aceh dan Muhammad Yusuf al-Maqasari yang berasal dari Sulawesi Selatan namun memulai karier intelektualnya ketika berada di Banten, Jawa Barat, Sri Langka dan Afrika Selatan.

1. Ar-Raniri

Ketika Syamsuddin Sumatrani dan Sultan Iskandar Muda meninggal, ar-Raniri datang ke Aceh, tepatnya pada 6 Muharram 1047/31 Mei1637, dia segera ditunjuk menjadi Syaikh al-Islam, salah satu kedudukan tertinggi di kesultanan di bawah Sultan Iskandar Tsani. Setelah mendapatkan pijakan kuat di Istana SultanAceh, ar-Raniri mulai melancarkan pembaruan islamnya di Aceh.Ar-Raniri hidup selama 7 tahun di Aceh sebagai seorang 'Alim, Mufti danpenulis produktif, yang mencurahkan banyak tenaga untuk menentang doktrinwujudiyah.

Ar-Raniri tidak serta mertamemperkenalkan beberapa madzhab fikih yang ada kepada masyarakat Aceh, namun ar-Raniri tetap mempertahankan madzhab masyarakat Aceh yang telah berlangsungbeberapa abad sebelumnya yaitu madzhab Syafi'i.

Ar-Raniri inginmengembalikan shariat bersamaan dengan tasawuf, beliau wujudkan dengan menulis kitab Shirat al-Mustaqim di tanahMelayu. Dalam karya ini dia menegaskan tugas pertama setiap orang muslim dalam hidupnya, adalah lurus/ konsisten sesuai dengan pengakuan imannya pada Allah SWT.tanpa berpaling sedikitpun pada yang lain. Dalam buku ini beliau menjelaskan berbagai hal seperti bersuci (wudhu) shalat, zakat, puasa, haji kurban dan semacamnya. Meski buku ini tampaknya hanya memberikan penjelasan sederhana atas aturan-aturanfikih dasar. Kita hendaknya tidak mengesampingkan makna pentingnya bagi kaum muslim Melayu-Indonesia pada masa itu ketika Tasawuf mendapatkan kesalah pahaman pada masa-masa sebelumnya.

Dalam bidang fikih dia mendasarkan pada buku-buku Syafi'iyah seperti MinhajalThalibin karya Imam Nawawi, Fath al-Wahhab bi Sharh Minhaj al-Thullab karyaZakariya al-Anshari. Hidayat al-Muhtaj bi Sharh al-Mukhtasar karya Ibn Hajar, kitabal-Anwar karya al-Fardubili atau Nihayat al-Muhtaj Ila Sharh al-Minhaj karya alNawawi karya Syams al-Din al-Ramli. ${ }^{10}$

\footnotetext{
${ }^{9}$ Zuhairini, dkk., Sejarah Pendidikan Islam, (Jakarta: Proyek Pembinaan Prasarana dan SaranaPerguruan Tinggi Departemen Agama RI, 1986), hlm. 127.

${ }^{10}$ Hawas Abdullah, Perkembangan Ilmu Tasawuf dan Tokoh-Tokohnya di Nusantara, (Surabaya: Al-Ikhlas, 1980), hlm. 29.
} 


\section{Al-Sinkili}

Abd al-Rauf b. Ali al-Jawi al-Fansuri al-Sinkili ( selanjutnya disebut Sinkili) adalah seorang Melayu dari Fansur, Sinkil (modern : Singkel) diwilayah pantai barat laut Aceh. Lahir pada tahun 1024/1615. ayah SinkiliSyaikh Ali adalah serong Arab yang mengawini seorang wanita dari Fansur kemudian bertempat tinggal di Singkel dimana anak mereka Abd Rauf dilahirkan.

Karya utama Sinkili dalam fikih adalah Mir'at al-hTullab fi Tashri'Ma'rifat alAhkam al-Shar'iyyah li al-Malik al-Wahhab. Karya ini ditulis atas permintaan Sultanah Shafiyyat al-Din, dijelaskan pada tahun 1074/1663. Tidak seperti Shirat al-Mustaqim karya ar-Raniri yang hanya membahas tentangibadah, Mir'at al-Thullab mengemukakan tentang aspek mu'amalat dari fiqih,termasuk kehidupan politik, sosial, ekonomi, dan keagamaan kaum muslim.

Sumber utamanya karya ini adalah Fath al-Wahhab karya Zakaria alAnshari.Sinkili juga mengambil bahan dari buku-buku standar seperti Fath al-Jawab dan Tuhfat al-Muhtaj, keduanya karya Ibn Hajar al-Haytsami (w. 973/1565); Nihayat alMuhtaj karya Syamsuddin al-Ramli; Tafsir al-Baidhawi karya Ibn Umar al-Baidhawi (w.685/1286) dan Syarh Sahih Muslim karya al-Nawawi (w. 676/1277).

Sinkili adalah ulama pertama di wilayah Melayu Indonesia yang menulismengenai Fiqh Mu'amalat. Melalui Mir'at Thullab dia menunjukkan kepada kaum muslim Melayu bahwa doktrin-doktrin hukum Islam tidak terbatas pada ibadah saja tetapi juga mencakup seluruh aspek kehidupan sehari-hari mereka.

\section{Al-Maqasari}

Muhammad Yusuf b. Abd. Allah Abu al-Mahasin al-Khalwati al-Maqassari juga dikenal di Sulawesi sebagai tuanta salmaka ri gowa (guru kamiyang agung dari Gowa). Menurut sejarah beliau dilahirkan di Gowa pada tahun1037/1627. ${ }^{11}$

Maqassari menulis karyanya diantaranya Saylaniah, dalam Muqadimah kitabnya Safinat Najah, bahwa dia menulis Muqadimah kitabnya tersebut ketika dia berada di Srilangka.

Kitab itu ditulis atas permintaan kawan-kawan Maqassari. Dengan keberadaannya Maqassari di Srilangka, tidak memutuskan kontak Maqasari dengan orang Nusantara. Ini terjadi karena orang Nusantara yang ingin pergi haji, transit dulu di Srilangka dan akhirnya bertemu dengan Maqasari. Dan para jama'ah haji inilah yang membawa karya Maqassari ke Indonesia. Maqassari menulis karya-karyanya dalam bahasa Arab yang sempurna.

Hampir semua karyanya bertemakan tasawuf. Dalam mengembangkan ajarannya, Maqassari sering mengutip pendapat para ulama dan sufi semacam al-Ghazali, Junayd alBaghdadi, Ibn Arabi, al-Jilli, Ibn Atha'illah dan yang lainnya. Konsep utama tasawuf Maqassari adalah pemurnian kepercayaan pada keesaan Tuhan. ${ }^{12}$

\footnotetext{
${ }^{11}$ Azyumardi Azra, Jaringan Ulama Timur Tengah dan Kepulauan Nusantara Abad XVIIdan XVIII, (Bandung: Mizan, 1998), hlm. 212.

${ }^{12} \mathrm{Ibid}$.
} 


\section{Pemikiran Hukum Islam di Indonesia}

Istilah hukum Islam menurut Hasbi Ash-Shiddieqy seperti dikutip Amir Syarifuddin adalah koleksi daya upaya para ahli hukum untuk menerapkan syariah atas kebutuhan masyarakat. ${ }^{13}$ Jadi hukum Islam adalah peraturan-peraturan yangdirumuskan berdasar wahyu Allah dan sunah Rasul-Nya tentang tingkah laku mukallaf yang diakui dan diyakini berlaku mengikat bagi semua pemeluk Islam. Dengan demikian, kedudukan hukum Islam sangat penting dan menentukanpandangan hidup serta tingkah laku Muslim. ${ }^{14}$ Disinilah hukum Islam merupakan formulasi dari syariah dan fikih sekaligus.

Hukum Islam dalam perjalanan sejarahnya yang awal merupakan suatu kekuatan yang dinamis dan kreatif. Hal ini dapat dilihat dari munculnya sejumlah mazhab hukum yang memiliki corak sendiri-sendiri sesuai dengan latar belakang sosiokultural dan politik dimana mazhab hukum itu tumbuh dan berkembang. Perkembangan yang dinamis dan kreatif ini setidak didorong oleh empat faktor utama: pertama,dorongan keagamaan, karena Islam merupakan sumber norma dan nilai normatifyang mengatur seluruh aspek kehidupan umat Islam,Kedua, dengan meluasnya domain politik Islam pada masa khalifah Umar terjadi pergeseran-pergeseran sosial yang pada gilirannya menimbulkan sejumlah besar problem baru sehubungan dengan hukum Islam. Ketiga, independensi para spesialis hukum Islam dari kekuasaan politik. Keempat, fleksibilitas hukum Islam yang memampukannya untuk berkembang mengatasi ruang dan waktu. ${ }^{15}$

Menurut Hasbi Ash-Shiddiqiey terdapat lima prinsip yang memungkinkan hukum Islam dapat berkembang mengikuti masa: 1) prinsip ijmak; 2) prinsip qiyas; 3) prinsip maslahah mursalah; 4) prinsip memelihara 'urf; dan 5) berubahnya hukum dengan berubahnya masa. Kelima prinsip ini dengan jelas memperlihatkan betapa fleksibelnya hukum Islam. ${ }^{16}$

Muhammad Natsir dalam tulisannya menyebutkan bahwa dalam penegakan system hukum Islam setidaknya ada empat hal kewajiban negara dalam menegakkan hukum Islam dan melindungi rakyat. Keempat hal tersebut yaitu: pertama, memelihara agama supaya tetap pada dasar yang telah ada; kedua: melindungi daerah kawasan; ketiga: melaksanakan hukum had; dan keempat: menjalankan putusan hakim bagi para pihak yang bersengketa. ${ }^{17}$

Menurut Abdul Manan terdapat tiga dimensi yang harus dilihat jika hukumIslam akan diperbarui dalam pengertian fikih. Pertama, perubahan secara menyeluruh pada doktrin, yaitu mengubah nilai-nilai yang terkandung dalam fikih yang sudah tidak sesuai lagi dengan kondisi, situasi, tempat dan waktu harus diperbarui agar sesuai dengan

\footnotetext{
${ }^{13}$ Amir Syarifuddin, Pengertian dan Sumber Hukum Islam, dalam Ismail Muhammad Syah,Filsafat Hukum Islam, Cet. I, (Jakarta: Bumi Aksara, 1992), hlm. 18.

${ }^{14}$ Ahmad Rofiq, Pembaharuan Hukum Islam di Indonesia, (Yogyakarta: Gama Media,2001), hlm. 23.

15 Ibid.

16 Taufiq Adnan Amal, Islam dan Tantangan Modernitas; Studi atas Pemikiran HukumFazlur Rahman (Bandung: Mizan, 1989), hlm. 33-35.

17 Muhammad Natsir, Membangun Hukum Pidana Lingkungan Berbasis Syariah di Aceh, (Yogyakarta: Deepublish, 2018), hlm. 7
} 
kondisi zaman. Kedua, pembaruan dalam cara penerapannya, dalam hal ini Abdul Manan memberikan contoh dalam kecenderungan mengutamakan penerapan fatwa atau syarah ulama yang sudah tidak relevan lagi dengan konteks zaman, maka harus ditinggalkan. Ketiga, pembaruan pada kaidah (aturan) yang sesuai dengan kondisi dan situasi sosial masyarakat Indonesia dan dilegalisasi oleh instansi yang berwenang sehingga mempunyai kekuatan hukum yang mengikat. ${ }^{18}$

Ketiga dimensi pembaruan tersebut dapat dijadikan sebagai agenda besar dalam pembaruan hukum Islam di Indonesia yang berada pada tiga tempat yaitu: pertama, tersebar dalam kitab-kitab fikih yang ditulis oleh para fukaha ratusan tahun yang lalu. Kedua, berada dalam peraturan perundang-undangan Negara yang memuat hukum Islam seperti Undang-undang Nomor 1 Tahun 1974 tentang Perkawinan, Peraturan Pemerintah Nomor 9 Tahun 1975, Kompilasi Hukum Islam dan sebagainya. Ketiga, terdapat dalam berbagai putusan Hakim Pengadilan Agama yang telah berbentuk yurisprudensi. Namun ketiga sumber hukum Islam di Indonesia tersebut, pada realitasnya sering terjadi kontroversi pada penerapanya baik antara fikih dengan peraturan perundang-undangan yang berlaku, atau antara fikih dengan putusan Pengadilan Agama, bahkan antara putusan Pengadilan Agama dengan peraturan perundang-undangan yang berlaku. ${ }^{19}$

Hukum Islam sangat mengedepankan konsep tahqiq problematika kemanusiaan atau merealisasikan kemaslahatan umat manusia. Dapat dipahami dengan jelas bahwa prinsip keadilan merupakan kata kunci dalam hukum Islam. Meski harus diakui bahwa manusia kadang-kadang mengalami kesulitan untuk menangkap prinsip-prinsip dan norma-norma keadilan yangditujukan Tuhan dalam syariat-Nya menurut aturan nalarnya, terlebih lagi yang menyangkut hubungan vertikal manusia dengan Khaliknya.

Al-Syatibi dalam kitabya Al-Muwafaqatfi Usul al-Ahkam, mengemukakan sebuah kaidah:

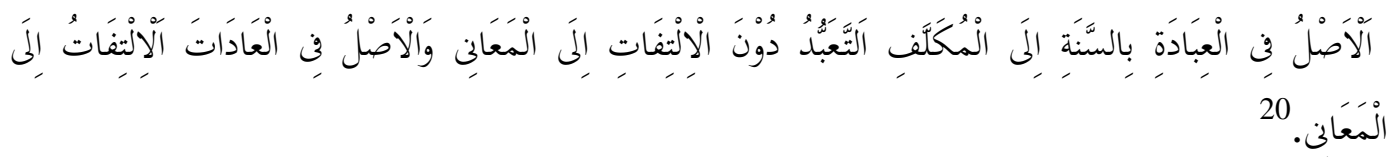

Artinya: Pada prinsipnya dalam masalah ibadah, diterima dan dipatuhi, tidak berpaling pada rasionalisasi makna, dan pada prinsipnya dalam masalah adat adalah berpaling kepada rasionalisasi makna.

Dengan demikian, ruang gerak pembaruan hukum Islam adalah dalam hal-hal yang berkaitan dengan permasalahan adat atau muamalah. Dalam hal ini pula akal atau rasio dapat memberikan pertimbangan mana yang dan bermanfaat dan mana yang mendatangkan mudarat bagi kehidupan manusia. Pada dasarnya hukumIslam, baik dalam pengertian syariah maupun dalam pengertian fikih secara ringkas dapat dibagi dua yaitu: 1) bidang ibadah; dan 2) bidang muamalah.

\footnotetext{
${ }^{18}$ Abdul Manan, Reformasi Hukum Islam di Indonesia, (Jakarta: Rajawali Press, 2006), hlm. 7.

${ }^{19}$ Ibid., hlm. 11 .

${ }^{20} \mathrm{Abu}$ Ishaq Ibrahim al-Syatibi, al-Muwafaqat fi Ushul al-Ahkam, vol. II (Kairo: Matba'atMuhammad 'Ali Subaih, 1970), hlm. 211.
} 
Aspek ibadah ini berlaku asas umum yakni semua perbuatan ibadah dilarang dilakukan kecuali perbuatan-perbuatan yang dengan tegas ada perintah untuk dilakukan petunjuk-petunjuk yang menyatakan bahwa itu adalah perbuatan suruhan yang terdapat di dalam Alquran dan hadis yang memuat sunah Rasulullah. ${ }^{21}$ Jika dihubungkan dengan alahkam, al-khamsah atau hukum taklifi, kaidah ibadah adalah larangan (haram).

Di Indonesia, salah satu system hukum yang berlaku adalah hokum Islam. ${ }^{22}$ Dalam sistem hukum Islam tersebut di dalamnya terdapat setidaknya ada empat jenis produk hukum Islam yang telah berkembang dan berlaku di Indonesia, yaitu: Fikih, Fatwa ulama, hakim, keputusan pengadilan, Yurisprudensi, dan Perundang-undangan. ${ }^{23}$

Pemikiran hukum Islam yang lain adalah keputusan Pengadilan Agama. Keputusan Pengadilan Agama bersifat mengikat kepada pihak-pihak yang berperkara. Meskipun sebagai produk lembaga yudikatif, keputusan pengadilan dapat bernilai yurisprudensi yang dalam kasus-kasus yang sama dapat menjadi rujukan sebagai reprensi hukum Islam. Keputusan pengadilan adalah bersifat dinamis, karena ia merupakan usaha untuk memberi jawaban atau menyelesaikan masalah yang diajukan kepada pengadilan pada suatu titik waktu tertentu. ${ }^{24}$

Empat produk pemikiran hokum Islam tersebut, mengandung nilai-nilaisosial yang tumbuh dalam masyarakat. Rumusan-rumusan yang ada dalam fikih adalah hasil penalaran dan pengkajian para ulama tentang Alquran dan hadis yang mereka hubungkan dengan kondisi masyarakat. Demikian pula fatwa tidaklah begitu saja lahir. Fatwa dilakukan, karena adanya persoalan-persoalan hukum dalam masyarakat yang memerlukan jawaban yang relatif cepat.

Dalam budaya hukum, undang-undang lahir biasanya setelah ketiga produk pemikiran hukum Islam tersebut dipraktikkan oleh masyarakat dalam sebuah proses waktu dan adaptasi kondisi yang akhirnya diangkat sebagai sebuah perundang-undangan yang mempunyai sanksi hukum.

Hukum Islam bukan hanya dijadikan rujukan prilaku, tetapi juga sebagai elastisitas berprilaku. Pemikiran hukum Islam dapat berubah karena berubahnya waktu, zaman, tempat dan kondisi sosial masyarakat. Perubahan itu menjadikan berubahnya pula berprilaku keagamaan dan berprilaku budaya, dengan catatan tidak bertentangan dengan prinsip Alquran dan hadis. ${ }^{25}$

Salah satu kaidah yang dikenal dalam pemikiran hukum Islam dan berhubungan dengan kearifan local adalah "al adaatul Muhakkamaat". Kaidah ini memberikan petunjuk bahwadalam merumuskan hukum Islam, pendekatankultural yang berkaitan denganadat, tradisi masyarakat yang sifatnya lokal atau disebut al-urf (kebiasaan

\footnotetext{
${ }^{21}$ Muhammad Daud Ali, Hukum Islam, Pengantar Ilmu Hukum dan Tata Hukum Islam diIndonesia, Edisi VI, Cet. IX,(Jakarta: Raja Grafindo Persada, 2000), hlm. 49.

${ }^{22}$ Mohammad Daud Ali,Hukum Islam Pengantar Ilmu Hukum danTata Hukum Islam Indonesia, Edisi ke 6(Jakarta: PT RajaGrafindo Persada, 2007),hlm. 207.

${ }^{23}$ Ahmad Rafiq, Hukum Islam diIndonesia (Jakarta: PT. RajaGrafindoPersada, 1998), hlm. 24-25.

${ }^{24}$ M. Atho Mudzar, Fikih danReaktualisasi Ajaran Islam, Makalah SeriKKA 50Tahun V, (Jakarta: YayasanWakaf Paramadina, 1991), hlm. 1-2.

${ }^{25}$ Beni Ahmad Saebani,Sosiologi Hukum (Cet. I; Bandung:Pustaka Setia, 2007), hlm. 94.
} 
kebiasaan masyarakar yang bersifat normatif) merupakan suatu pertimbangan yang penting.

Dalam perkembangan pemikiran hukum Islam yang dirumuskan oleh para imam mujtahid, pada mulanya sangat ketat dengan nas, tetapi pase-pase berikutnya selain nas juga memperhatikan kearifan lokal.

Ibn al-Qayyim al-Jawziyah dalam I'lam al-Muwaqqi'in 'an Rabbi 'alalamin, beliau menulis satu bab yang berbunyi:

$$
\text { تغير الفتوى واختلا فها بحسب تغير الازمنة والامكنة والا حوال والنيات والعوائد }
$$

Artinya: Perubahan fatwa mengenai hukum Islam dan perbedaannya tergantung pada perubahan waktu, tempat, keadaan, niat dan tradisi). ${ }^{26}$

Perubahan-perubahan hukum tersebut, dapat diperhatikan kembali bagaimana Imam Syafi'i merubah pemikiran hukumnya ketika dia berada di Irak dan ketika berada di Mesir (disebut qawl qadim). Munculnya qawl jadid merupakan dampak dari perkembangan baru yang dialami oleh Imam Syafi'i; dari penemuan hadis, pandangan dan keadaan sosial baru yang dia tidak temukan selama tinggal di Irak dan Hijaz.

Berdasarkan kenyataan tersebut, Mun'im A. Sirry berkesimpulan bahwa qawl jadid merupakan suatu refleksi dari kearifan lokal pada dua tempat yang berbeda. ${ }^{27}$ Kaidah yang di kemukakan di atasmemberikan pemahaman bahwa produkpemikiran hukum Islam selalu bersinergidengan kearifan lokal yang telah dipatuhi oleh masyarakat dalamberinteraksi. Begitu juga hukum Islamselalu memperhatikan keadaan-keadaan sosial dengan segala macam perubahandan perkembangannya. ${ }^{28}$

Pemikiran hukum Islam yang dikembangkan oleh para ulama merupakan perwujudan dari pembumian hukum Islam yang pada prinsipnya selalu sesuai dengan ruang dan waktu. Pemikiran hukum Islam yang ada di Indonesia, baik yang masih tataran wacana maupun yang sudah menjadi produk hukum Islam, sedikit banyaknya dipengaruhi oleh kearifan lokal dan kondisi riil masyarakat Indonesia.

Masyarakat Indonesia, baik yang bermukim pada komunitas tertentu maupun yang berada secara umum di seluruh wilyah nusantara, laki-laki dan perempuan saat ini relatif setara dalam membantu orang tua atau mencari rezeki secara umum. Olehnya itu, dengan tidak bermasud melecehkan hukum yang terdapat dalam Alquran dan hadis, pembahagian warisan antara anak laki-laki dan perempuan adalah hal yang tidak ekstrim melanggar syariat jika disesuaikan dengan kearifan lokal masyarakat Indonesia tersebut.

Khususnya harta gono gini, secara sosiologis memiliki landasan hokum yang sangat kuat sebagai hasil kompromi dengan nilai-nilai hukum adat atau kearifan lokal yang hidup dalam masyarakat Indonesia. Mengingat kapsitas dan peran isteri sebagai

${ }^{26}$ Ibn Qayyim al-Jawziyah,I'lam al-Muwaqqi'in 'an Rabb al-'Alamin(Bairut: Dar al-Kutub alHadisah, t.th.), hlm. 5.

${ }^{27}$ Jaih Mubarok, ModifikasiHukum Islam Studi tentang Qawl Qadimdan Qawl Jadid,Cet. I,(Jakarta: PTRajaGrafindo Persada, 2002), hlm. 10.

${ }^{28}$ F. James Davis, TheSosiological Study of Law (New York:Free Press ad Glencoe, 1962), hlm. 77. 
pendamping suami dan sebagai ibu rumah tangga yang sangat besar andilnya dalam mengumpulkan harta kekayaan dan mengurus intern rumah tangga, sehingga dengan peran isteri tersebut secara hakiki sama dengan bekerja.

Apalagi, jika isteri berperan ganda, di samping tidak mengabaikan kewajibannya dalam rumah tangga juga juga bekerja membantu suami dalam mengumpulkan harta kekayaan. Dengan demikian, lembaga harta bersama diIndonesia yang bersumber dari kearifan lokal akan dapat menegakkan asas keseimbangan antara hak dan kewajiban suami isteri, sekaligus memenuhi prinsip pokok keadilan yang ada dalam Alquran dan hadis. ${ }^{29}$

Pemikiran hukum Islam yang lain di Indonesia, seperti perkawinan, zakat, haji dan peraturan-peraturan lain yang berkaitan dengan hukum perdata Islam,baik yang belum dirumuskan dan diberlakukan maupun yang sudah diberlakukan.

\section{Penutup}

Pemikiran hukum Islam yang sudah melembaga dan dipatuhi oleh masyarakat Indonesia adalah fiqih, fatwa ulama-hakim, keputusan pengadilan (Yurisprudensi) dan perundang-undangan. Proses lahirnya keempat hal tersebut tidak lepas dari perkembangan dinamika kehidupan masyarakat Indonesia.

Pemikiran hukum Islam yang diadopsi dalam pembangunan hokum Islam di Indonesia, sudah lama dicanangkan oleh para ulama hokum Islam di dunia Islam dengan berbagai macam karya yang mereka lahirkan. Para ulama hukum Islam tersebut seperti Imam Syafi'i, Imam Ahmad bin Hanbal dan ulama-ulama sesudahnya.

Eksistensi kearifan lokal menjadikannya sebagai bahagian pertimbangan dalam setiap pemikiran hukum Islam di Indonesia, seperti hukum perkawinan dan kewarisan sangat menghargai kehidupan sosial masyarakat, baik yang ada dan berkembang sejak dahulu maupun perkembangan kehidupan sosial masyarakat.

\section{Daftar Kepustakaan}

Abdul Manan, Reformasi Hukum Islam di Indonesia,Jakarta: Rajawali Press, 2006.

Abu Ishaq Ibrahim Al-Syatibi, al-Muwafaqat fi Ushul al-Ahkam, vol. II,Kairo: Matba'atMuhammad 'Ali Subaih, 1970.

Ahmad Rafiq, Hukum Islam di Indonesia, Jakarta: PT. RajaGrafindoPersada, 1998.

Ahmad Rofiq, Pembaharuan Hukum Islam di Indonesia, Yogyakarta: Gama Media, 2001.

Amir Syarifuddin, Pengertian dan Sumber Hukum Islam, dalam Ismail Muhammad Syah, Filsafat Hukum Islam, Cet. I, Jakarta: Bumi Aksara, 1992.

\footnotetext{
${ }^{29}$ Dedi Supriyadi, SejarahHukum Islam (Dari Kawasan JazirahArab SampaiIndonesia), Cet. I,(Bandung: Pustaka Setia, 2007), hlm. 416.
} 
Lurnas $\mathscr{H u k u m}$

Volume 14, Nomor 1, Januari-Juni 2019

Atho Mudzar M., Fikih dan Reaktualisasi Ajaran Islam, Makalah SeriKKA 50Tahun V, Jakarta: Yayasan Wakaf Paramadina, 1991.

Azyumardi Azra, Jaringan Ulama Timur Tengah dan Kepulauan Nusantara Abad XVIIdan XVIII, Bandung: Mizan, 1998.

Beni Ahmad Saebani, Sosiologi Hukum, Cet. I, Bandung: Pustaka Setia, 2007.

Bustanul Arifin, Dimensi Hukum Islam dalam Hukum Nasional, Gema Insani Press, 1999.

Dedi Supriyadi, Sejarah Hukum Islam (Dari Kawasan Jazirah Arab Sampai Indonesia), Cet. I, Bandung: Pustaka Setia, 2007.

Hasbullah, Sejarah Pendidikan Islam di Indonesia, Jakarta: Raja Grafindo Persada, 1999.

Hassan Muarif Ambary, Menemukan Jejak Arkeologis dan Historis Islam, Jakarta: Logos, 1998 .

Hawas Abdullah, Perkembangan Ilmu Tasawuf dan Tokoh-Tokohnya di Nusantara, Surabaya: Al-Ikhlas, 1980.

Ibn Qayyim Al-Jawziyah, ,I'lam al-Muwaqqi'in 'an Rabb al-'Alamin, Bairut: Dar alKutub al-Hadisah, t.th.

Ismail Sunny, Kompilasi Hukum Islam Ditinjau dari Teori Hukum, dalam TimDitbinbapera, Berbagai Pandangan Mengenai Kompilasi Hukum Islam, Jakarta: Yayasan Al Hikmah, 1996.

Jaih Mubarok, Modifikasi Hukum Islam Studi tentang Qawl Qadim dan Qawl Jadid, Cet. I, Jakarta: PTRajaGrafindo Persada, 2002.

James Davis F., The Sosiological Study of Law, New York:Free Press ad Glencoe, 1962.

Mohammad Daud Ali, Hukum Islam Pengantar Ilmu Hukum dan Tata Hukum Islam Indonesia, Edisi ke 6, Jakarta: PT RajaGrafindo Persada, 2007.

Muhammad Natsir, Membangun Hukum Pidana Lingkungan Berbasis Syariah di Aceh, Yogyakarta: Deepublish, 2018

Muhammad Rifai, Sejarah Islam, Semarang: Wicaksana, 1985.

Said Aqil Husein Al-Munawwar, Islam dalam Pluralitas Masyarakat Indonesia, Jakarta: Kaifa,2004.

Taufiq Adnan Amal, Islam dan Tantangan Modernitas; Studi atas Pemikiran Hukum Fazlur Rahman, Bandung: Mizan, 1989. 
Lurnas Fukum

P-ISSN : 2615-3416

Samudra Keadilan

E-ISSN

: 2615-7845

Volume 14, Nomor 1, Januari-Juni 2019

Zuhairini, dkk., Sejarah Pendidikan Islam, Jakarta: Proyek Pembinaan Prasarana dan Sarana Perguruan Tinggi Departemen Agama RI, 1986. 